https://doi.org/10.15407/econlaw.2021.03.074

UDC 338.23:6281

D.T.D. ELRABAY'A, PhD student, Department of economics and entrepreneurship, Management and marketing college National Technical University of Ukraine "Igor Sikorsky Kyiv Polytechnic Institute", Kyiv, Ukraine (iD) orcid.org/0000-0001-8912-4664

V.M. MARCHENKO, Dr. of Sci. of Economics, Professor, Department of economics and entrepreneurship, Management and marketing college National Technical University of Ukraine "Igor Sikorsky Kyiv Polytechnic Institute", Kyiv, Ukraine (iD) orcid.org/0000-0002-4756-3703

\title{
THE LEGAL SUPPORT OF ORGANIZATIONAL AND ECONOMIC PROCESSES OF MUNICIPAL WASTE MANAGEMENT IN THE EUROPEAN UNION AND UKRAINE
}

Keywords: waste management, minimization, preventions, recycling, landfill.
The article clarifies the substantial organizational and economic risks ahead, on the way for Ukraine to meet its committed targets to transform waste management system to become in full accordance with those implemented in the European Union. Both, European and Ukrainian legislation in this regard are analyzed, categorized, and compared to highlight the core differences and identify the gaps in the ones that are implemented in Ukraine. The environmental and economic results of waste management in Germany and Ukraine revealed, that Ukraine is not demonstrating satisfactory improvement during the last 7 years since the association agreement was signed. The article identifies 5 key recommendations, that would allow Ukraine to match up with European countries in municipal waste management (household waste management according to Ukrainian classification system), these recommendation are summarized as follows: centralized legislation approach, where all essential regulations are approved by the central government and unified for all regions; promptness, and operative attitude to take all necessary actions related to waste management; guaranteeing measurability and control over each waste management stage, that should lead to creating fully informative digital database; implementing "Peeling away method" to ensure that all potential secondary raw material and high calorific value waste is reused of converted into alternative energy resources; and finally, creating comprehensive and cohesive legislative package that works all together as integrated system. Centralized/ local legislative distribution analysis, and structure of public information on waste in the official portal are provided for the first time in a scientific research, to the best knowledge of the authors. "The peeling away method", described in this article, is used for the first time as well, to explain in simple way, the European strategy to minimize the amount of waste that is sent to landfill.

Introduction. By signing the association agreement between Ukraine and the European Union (EU) in 2014, Ukraine has committed itself to transforming its environmental and waste management (WM) policies to be in

Ц и ту в ан н я: Elrabay’a D.T.D., Marchenko V.M. The legal support of organizational and economic processes of municipal waste management in the European Union and Ukraine. Економіка та право. 2021, № 3. C. 74-86. https://doi.org/10.15407/ econlaw.2021.03.074 
line with the European ones, as part of its path to joining the European community. Identifying gaps in the current WM legislation in Ukraine by comparing them with those, implemented in the most successful European countries in this area seems to be the most effective practice that could help Ukraine to build comprehensive one. Ukraine must demonstrate an extremely rapid transformation by 2030 in terms of waste prevention and minimization, achieving high recycling rates and reducing waste quantities that are sent to landfill. Legislation and regulations play a key role in achieving the desired goals at a reasonable cost. The integrity of the legislation, along with clear action plan to form the crux to achieve the end results.

Analysis of recent research and publications. Several researchers in the EU devoted their work to the deep analysis of the WM legal system, the most relevant ones to be mentioned are N. Faris and S. Lieberz [1], H. Schnurer [2], K. Weber, P. Quicker, J. Hanewinkel and Flamme S. [3], V.A. Zujev [4]. On the other hand, the study of waste management issues in Ukraine is reflected in the research of such scientists as G.V. Zhuk, Je. Nikitin, A.V. Smihula, O.V. Dutka and O.S. Ivaniv [5], N. Popovych, M. Malyovanyy, O. Telak, A. Voloshchyshyn and V. Popovych [6]. WM legal support issues and the directions to follow to improve national were investigated by S.V. Krivenko [7] and T.L. Omelyanenko [8]. All these research agreed that Ukraine is facing tremendous challenges to address. Recent studies in large Ukrainian cities have shown that simply copying Western European schemes does not give the desired effect, despite the pointless spending [5]. Research in Myronivka city has shown that extensive waste disposal has resulted in hazardous levels of toxins and volatile organic compounds [9]. Experts believe that such an unsatisfactory WM system performance in Ukraine is caused by the weak legal framework and economic problems [10]. Other articles argue that the lack of appropriate recycling plants and technologies in Ukraine is a major obstacle to reducing the accumulation of waste in landfills [6]. The predominance of administrative methods over economic ones and the lack of awareness among the local population on the advantages of the separate waste collection were also seen as additional challenges on the way to improve the situation [11]. As sustainability becomes more important for the EU population, the unsatisfactory situation with the collection and disposal of household waste in
Ukraine was perceived as a barrier to attracting investment and tourism [12].

The purpose of the article. To summarize the main provisions of the EU and Ukrainian legislation in the field of WM system regulation and develop recommendations to design a comprehensive and consistent legislative system and initiatives related to the level of governance centralization, waste minimization and performance monitoring parameters.

Results. The environmental and WM in the EU are governed by directives, decisions, and regulations, which together form the law for all EU countries [13]. The legal WM in the EU consists of two groups: general or framework directives, and directives that govern the entire WM cycle stages individually. General directives and decisions aim to create guidelines that formulate a holistic approach, while directives and decisions governing the MA cycle are more specific in terms of developing action plans, compliance criteria and control methods.

General and framework EU directives and decisions can be summarized as follows:

1. Directive 2004/35/CE of the European Parliament and of the Council of 21 April 2004 on environmental liability with regard to the prevention and remedying of environmental damage. This directive prioritizes the prevention of pollution, over eliminating its consequences. The directive builds on the "polluter pays" principle as the main pillar for the remediation of all contaminated sites. The public authorities in each country - in accordance with this directive - are obliged to ensure the implementation of this directive in order to conduct adequate remediation of the consequences of accidents. According to this directive, each EU member state is obliged to designate a competent authority, responsible for its implementation.

2. Directive 2008/98 / EC on waste. This directive forms the basis of the WM. The directive explained terms such as waste, prevention, recovery, recycling, and disposal. The basic principles enshrined in this directive can be summarized as follows:

a) the best practice in WM is to prevent the waste from being generated;

b) the introduction of product reuse and recycling is a priority. Actions to reuse, recover and recycle secondary raw material (SRM), and then, expand the use of alternative fuels to generate energy from the remaining waste, are priority actions to be taken prior to disposal. 
c) each EU member state should develop a comprehensive permitting system that regulates the entire WM cycle and ensures both traceability and accountability of each stakeholder;

d) payment for waste disposal in accordance with the "polluter pays" principle is made either by the owner of the waste or by the previous owner, who may be the producer;

e) each EU member state is obliged to incorporate the provisions of this law into its national laws;

f) each EU member state is obliged to report on the implementation of this directive.

3. Directive 2008/98/EC of the European Parliament and of the Council of 19 November 2008 on waste and repealing certain Directives. This directive set out more stringent approaches to achieving waste minimization targets. The main provisions in this directive are as follows:

a) new participants in the WM system have been identified: waste trader - a party that buys or sells waste, even if it does not take direct ownership of the waste; and a waste broker - a party that physically carries out waste treatment and disposal activities on behalf of the waste generator;

b) for the first time, separate waste collection became a mandatory WM practice;

c) a new WM hierarchy was introduced in the form of a law, this hierarchy focused on waste prevention and minimization in the following sequence: prevention by taking all measures before the substance becomes waste; reuse of products or their components for the same purpose; prepare products for reuse by cleaning, inspecting and reconditioning, after which they can be used again; recover valuable material from waste to create substitute material and finally; process substitute material to produce SRM.

d) rethinking products' life cycle was recommended as a new practice, and as a result, it would be expected that components could migrate between levels of the hierarchy in the interest of the environment and the economy;

e) the concept of "by-product" was also introduced;

f) the term "end of waste" was defined as the point at which a product ceases to be waste;

g) extended product liability was recommended as a legal process involving manufacturers of products that generate waste after use;

h) the directive set two main goals to be achieved by 2020: prepare for reuse and recycling up to $50 \%$ of material, such as glass, paper, metals, and plastics from household and other similar waste; and reuse and recycling of up to $70 \%$ of the other material for backfill and other purposes;

i) bio-waste must be collected separately and treated using aerobic or anaerobic process before reuse or disposal;

j) detailed reporting mechanisms is a rule to be followed. The mechanisms are to determine the type of information to be included in the WM plans and the reporting frequency.

4. Regulation (EC) No 2150/2002 of the European Parliament and of the Council of 25 November 2002 on waste statistics. This regulation was intended to ensure that businesses and individuals comply with the EU directives on waste. This regulation obliged all EU member states to review the WM activities, keep accurate records, and publish all relevant data in the online European statistics database (Eurostat).

Directives, decisions of EU laws that regulate the WM cycle can be summarized as follows:

1. European Parliament and Council Directive 94/62/EC of 20 December 1994 on packaging and packaging waste. This directive governs all measures to reduce the use of packaging due to its harm to the environment. It also identifies reuse and recovery as key steps in preventing this type of waste. A return policy was recommended as one of the measures to minimize waste. The main provisions of this directive are as follows:

a) new recycling targets were adopted, the new targets were set to be $65 \%$ of packaging and packaging waste by the end of 2025, and a minimum of $70 \%$ by the end of 2030 . Recycling rates to be achieved no later than December 31, 2025, were set to be $50 \%$ for plastics, $25 \%$ for wood, $70 \%$ for ferrous metals, $50 \%$ for aluminum, $70 \%$ for glass and $75 \%$ for paper and paperboard. Recycling rates by 31 December 2030 were set to be $55 \%$ for plastics, $30 \%$ for wood, $80 \%$ for metals, $60 \%$ for aluminum, $75 \%$ for glass and $85 \%$ for paper and paperboard. Reuse rate for any category individually should not fall below $30 \%$;

b) the directive obliged all participants to increase the proportion of reusable packaging.

2. Directive 2000/76/EC of the European Parliament and of the Council of 4 December 2000 on the incineration of waste. In this directive, incineration is recognized as one of the main technologies, used to minimize waste disposal but only if the emission criteria, limiting the levels of nitrogen 
oxides (NOx), sulfur dioxide (SOx), and heavy metals are met. Only non-recyclable waste was allowed for incineration. The directive set out clear technological and technical guidelines for the operation of incineration plants, such as licensing, critical operating parameters, organization of operations and execution of its protocols.

3. Council Directive 1999/31/EC of 26 April 1999 on the landfill of waste. This directive emphasized the importance of the "polluter pays", "proximity" and "self-sufficiency" principles. The directive accentuated the importance of the control and monitoring system of all disposed waste, and divided landfills into different classes depending on the type of waste accepted in each of them. The main points covered by this directive are summarized below:

a) the directive prescribed to reduce the amount of bio-waste sent to landfills to $15 \%$ of the total generated in 15 years;

b) each member state was obliged, in accordance with this directive, to establish application systems for issuing permits for each waste shipment to that is intended to be disposed of;

c) each member state was obliged to ensure that all costs associated with the landfill life cycle are paid by waste generators in full compliance with the "polluter pays" principle, and to enact national laws and regulations in accordance with this directive.

The efficiency of the existing WM directives and decisions in the EU is evidenced by the recycling indicator, that show consistent increase. In the period from 2000 to 2018 , the waste that was processed increased by $87.5 \%$, the amount of waste that was sent to the landfill decreased by 2.5 times (Table 1).

Table 1. Household waste generation and processing in the EU, MT

\begin{tabular}{|l|c|c|c|c|c|c|c|}
\hline & \multicolumn{7}{|c|}{ Year } \\
\cline { 2 - 8 } & 2000 & 2005 & 2010 & 2015 & 2016 & 2017 & 2018 \\
\hline Disposal & 140 & 110 & 93 & 64 & 60 & 58 & 57 \\
Incineration & 39 & 48 & 57 & 65 & 68 & 70 & 70 \\
Recycling & 40 & 52 & 63 & 71 & 73 & 74 & 75 \\
Composting & 24 & 29 & 34 & 38 & 41 & 42 & 43 \\
Other & 12 & 17 & 6 & 6 & 6 & 6 & 6 \\
Total & 244 & 256 & 253 & 244 & 248 & 250 & 251 \\
Multiple reuse & 16,4 & 20,3 & 24,9 & 29,1 & 29,4 & 29,9 & 29,9 \\
\hline
\end{tabular}

Compiled according to [Eurostat]

\section{Cascading EU directives in Germany.}

The Federal Ministry for the Environment, Nature Conservation and Nuclear Safety (BMU) is responsible for drafting the relevant laws approved by the Bundestag. Control and monitoring of the implementation of approved laws is also within the competence of the BMU [14]. The WM in Germany is governed by laws and regulations issued by the Bundestag, these regulations can also be divided into the same two groups: general framework laws, and laws, regulating the WM cycle.

General framing Laws in Germany can be summarized as follows:

1. Act for promoting closed substance cycle waste management and ensuring environmentally compatible waste disposal from 27.09.1994. This law fully complies with EU directives. It set waste prevention as priority. It also defined the principles, obligations, and requirements through the entire WM system. The main provisions of this act are provided below:

a) compulsory prevention measures include low-waste product by design, changing consumption behavior, using low-waste products, and encouraging the production of alternative energy from waste by limiting mass incineration to reduce waste;

b) the waste disposal should be carried out without harm to the population and the environment;

c) waste generators are to dispose of waste that cannot be recycled in a safe way and submit detailed reports to officials and the public;

d) manufacturers are compelled to develop and produce durable products that can be reused and required to use RSM in their products;

e) all those who produce more than 2 tons of waste per year ought to provide comprehensive information about them to the authorities, which, in turn, must submit reports on the analysis of waste, including comparative analysis with previous years, to the relevant central authorities.

2. Act reorganizing the law on closed cycle management and waste of 24 February 2012. This act is a transposition of the EU directive on waste. The most important provisions of this act state that:

b) the waste producer is obliged to dispose of his waste in an environmentally friendly way;

c) mixing and dilution of waste of different nature is prohibited;

d) waste containers and collection services should be provided in compliance with all measures to ensure safe recycling; 
e) biological waste must be collected separately, processed with subsequent use in a circular economy only if it is safe to do so;

f) separate collection of paper, metals, plastics, and glass is mandatory if it is technically possible and economically feasible;

g) the share of solid waste preparation for reuse and recycling activities should be $70 \%$ by January 1,2020 ;

h) only those wastes that cannot be reused or recycled can be sent for disposal;

i) Manufacturers of products that can generate waste are responsible for taking all necessary steps to develop products that can be reused, and responsible for the use of recycled materials in their products, labeling products containing pollutants, providing adequate information, and accepting goods after their use as well as their waste.

Ordinances and regulations governing the WM cycle in Germany can be summarized as follows:

1. Packaging ordinance of 1April 2009. This regulation came into force defining the action plans and targets related to packaging recycling. It was replaced by an updated law with some changes related to the control of the life cycle of packaging waste. The ordinance confirmed that [1]:

a) packaging manufacturers are required to register their product using the online platform;

b) the manufacturer must report the amount of packaging accepted using the same online platform;

c) the manufacturer commits to achieve the following recycling targets by 2022: glass $-90 \%$, cardboard and cardboard - $90 \%$, ferrous metals $90 \%$, cardboard packaging for drinks $-80 \%$, other composites $-70 \%$, plastics $-90 \%$ and mechanical recovery (plastics) $-63 \%$.

2. Ordinance on environmentally compatible storage of waste from human settlements and on biological waste-treatment facilities of 20 February 2001. This ordinance was intended to regulate waste disposal. The first regulation in Germany on this matter was issued back in 1972, but didn't lead to major changes, that's why it was changed in 1993. This ordinance insisted on the following principles:

a) SRM or any other recoverable material cannot be sent to landfill;

b) mixed and bio-waste are not allowed to be landfilled without stabilization;

c) waste with a calorific value of more than $6 \mathrm{MJ} / \mathrm{kg}$ should be directed to incineration with subsequent generation of electricity prior to depositing in landfills; d) landfill operators must adhere to strict procedures for the registration, control and monitoring of waste, the authorities must have access to audit the records at all times.

As a result of the issuance and implementation of the aforementioned ordinances, Germany managed to alter the MW classification system to bring it in full accordance with the Bundestag's 2012 Circular and Waste Management Act. Valuable SRM was removed from the household waste list. Glass, paper, wood, packaging materials and organic waste were classified as separate categories that cannot be mixed with the remaining waste [15]. Eventually, Germany managed to demonstrate outstanding achievement, that can be categories as follows:

1. Waste prevention. Waste generation per capita decreased from 623 to $615 \mathrm{~kg} /$ year between 1995 and 2018 [16]. Considering factors such as population growth and GDP, Germany is one of the world leaders in decoupling economic growth and waste disposal rates.

2. Recycling. In Germany, recycling rate peaked at $64 \%$ in 2017 and was projected to continue in 2018. This is a colossal achievement considering the low starting point of $5 \%$. The main factor behind this success was the high recycling rate of packaging waste, which reached $70 \%$ in 2017, that was $27 \%$ higher than the targets set by the European Commission (EC) and the European Parliament (EP) [16].

3. Green energy production. The latest reports have shown that there are 66 municipal waste incinerators currently in operation in Germany, covering $3.7 \%$ of the country's energy needs. By 2016, licensed installations were able to burn 20.2 million tons of waste, that can't be recycled otherwise, using the most advanced technologies [3].

General and framework WM laws in Ukraine.

The main documents laying down the legal basis for WM in Ukraine are the Law "On waste", adopted back in 1998, and the Law "On environmental protection", adopted in 1991. Since their adoption, both laws have undergone significant changes and additions, considering the requirements of the association agreement with the EU.

The Law of Ukraine "On waste" defines the main directions of state policy in the field of WM, which are:

a) ensuring the complete collection and timely disposal of waste, as well as the compliance with environmental and safety rules when handling it; 


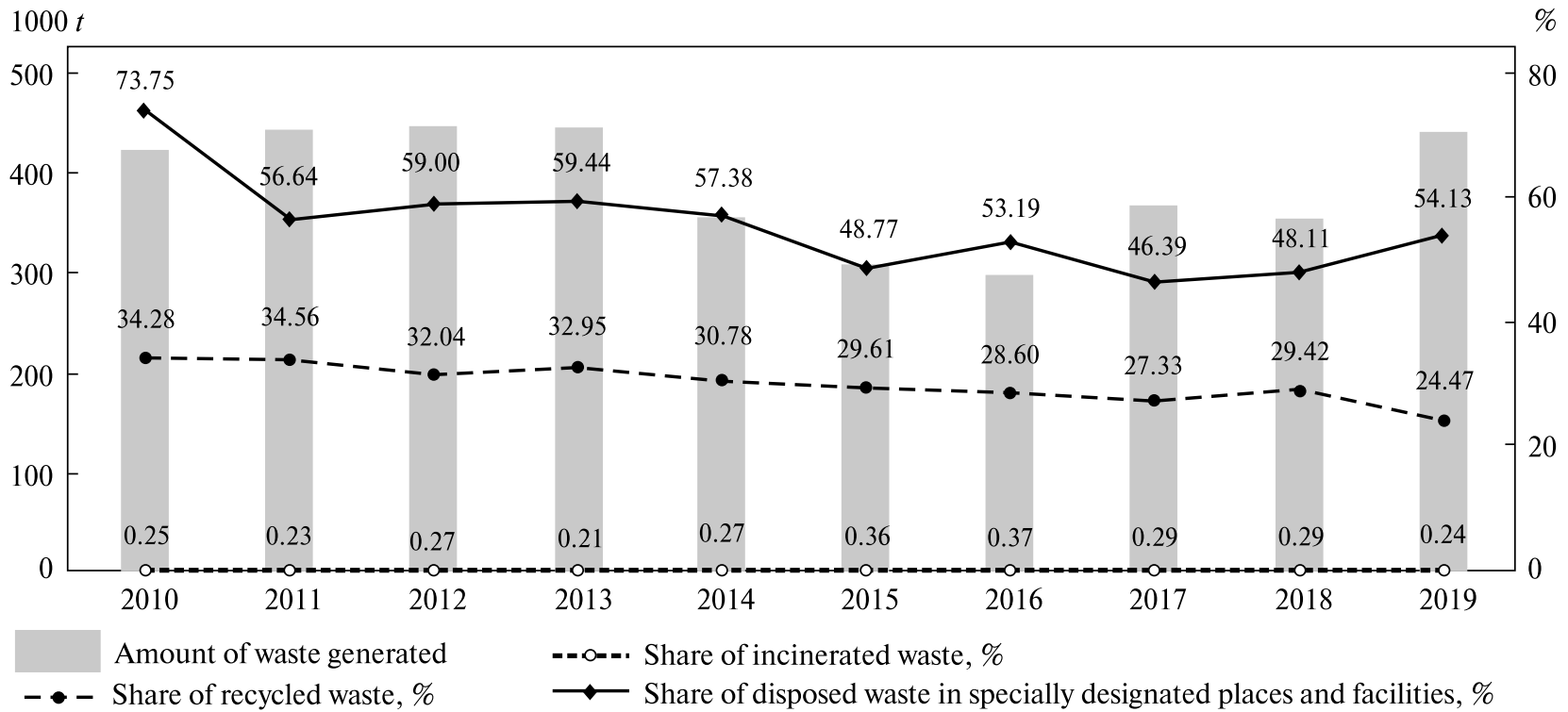

Fig. 1. Waste generation and MW in Ukraine

b) minimizing waste generation and reducing their hazard;

c) ensuring the integrated use of material and raw materials;

d) promoting waste treatment through direct reuse, or alternative use of SRM;

e) ensuring safe disposal of waste that cannot be recycled by developing appropriate technologies, environmentally friendly methods and means of waste management.

The Law "On environmental protection" has established the principle of environmental safety as the main rule for the protection of all types of resources and material security. The directions of state policy are quite consistent with the recycling rate WM Directives, implemented in the EU however, the analysis of the results of their implementation led to undeniable conclusion related to its slow implementation on the ground. During 2010-2019, stable trends could be observed in MW utilization and incineration. While changes were observed in waste generation rates, a dip in the volume of waste generated, evident 2014 was due to the fact that statistical data excluded the temporarily occupied territories in Donetsk and Luhansk regions (Fig. 1).

Table 2. Generation and handling of household waste in Ukraine

\begin{tabular}{|c|c|c|c|c|c|}
\hline \multirow[b]{2}{*}{ Year } & \multirow[b]{2}{*}{$\begin{array}{l}\text { Generated household } \\
\text { waste, million } \mathrm{m}^{3}\end{array}$} & \multirow[b]{2}{*}{$\begin{array}{l}\text { Recycled and utilized } \\
\text { household waste, \% }\end{array}$} & \multicolumn{2}{|r|}{ Out of which, $\%$} & \multirow{2}{*}{$\begin{array}{l}\text { Waste sent } \\
\text { to landfill, } \\
\text { million ton }\end{array}$} \\
\hline & & & Incinerated & $\begin{array}{c}\text { Received at procurement } \\
\text { points of SRM and waste } \\
\text { processing plants }\end{array}$ & \\
\hline 2013 & 59 & 3.65 & 1.15 & 2.5 & 13 \\
\hline 2014 & 45 & 4.2 & 1.7 & 2.5 & 10 \\
\hline 2015 & 48 & 5.93 & 2.73 & 3.2 & 10 \\
\hline 2016 & 49 & 5.8 & 2.71 & 3.09 & 11 \\
\hline 2017 & 52 & 6.6 & 2.48 & 4.18 & 10 \\
\hline 2018 & 54 & 6.2 & 2 & 4.2 & 9 \\
\hline 2019 & 53 & 6.1 & 2 & 4.1 & 10 \\
\hline 2020 & 54 & 6.3 & 1.7 & 4.6 & 10 \\
\hline
\end{tabular}

Compiled according to [State of the household waste management in Ukraine for 2013-2020] ${ }^{1}$

1 URL: https://www.minregion.gov.ua/napryamki-diyalnosti/zhkh/terretory/ 
According to the State Statistics Committee of Ukraine, more than half of the generated waste is stored in landfills. In addition, the total volume of waste accumulated in disposal and storage facilities increased by $26 \%$ during the period 2014-2019 [17].

According to the Ministry of Development of Communities and Territories of Ukraine, today in Ukraine only $4.6 \%$ of the total generated household waste is processed (Table 2).

The majority of household waste was disposed in unauthorized landfills. Ukraine is facing a challenge related to the limited capacity of existing landfills, which led to the increase in the number of unauthorized disposal sites their number fluctuates between 23-30 thousand sites (Table 3).

Waste incineration in Ukraine is carried out at the only operating waste incineration plant in Kyiv with a capacity of 300,000 tons per year. In total, there are 4 waste incineration plants in Ukraine (out of which, three are not functioning). The construction of a new plant has begun in L'viv. The statistics are a vivid explanation of the reasons for the low SRM recovery rate.

The difference between the situation with waste in Ukraine and other developed countries, is not only in the large volumes of waste generated but, also in the small number of regional processing capacities, and in the absence of adequate waste handling infrastructure. On the legislative level, it was revealed that the management of all waste processes, including collection, transportation, recovery, and disposal are carried out mostly by local executive authorities. The private sector occupies only $22 \%$ of the waste management market in Ukraine. The low investment attractiveness of waste management is due to the relatively low, in comparison with European countries, incomes of the population, thus, incapability to pay fair waste management tariffs, residents pay tariffs as part of utility bills.

The persistent growth of household waste generation in Ukraine created a real environmental threat and a deterioration in the quality of life in those areas, adjacent to waste disposal sites. Based on the current data, it was found that despite the presence of the Law "On Waste", which defined the general legal framework for WM and clearly formulated the directions of state policy in this field. Statistics indicate the absence of cardinal shift towards waste prevention and minimization. The trends testify the incompleteness of the WM regulations, which creates distortions across the waste hierarchy. The national waste management strategy in Ukraine until 2030, approved by the Cabinet of Ministers of Ukraine in 2017 can be perceived as an attempt to tackle waste management challenges. The strategy is based on adherence to a waste hierarchy, with waste disposal being the least favorable option, while prevention, reuse, recycling, and all forms of alternative energy production from waste are prioritized. It called for the creation of a Coordination Council headed by a Deputy Prime Minister. The strategy also demands to create a central body that takes responsibility for fulfilling all international environmental commitments on the local level in the regions. It also urged the development of alternative waste classification systems, and the introduction of effective monitoring and information databases. It obliged to modernize infrastructure to reduce waste and improve efficiency, digitize the WM industry, and concentrate information on one portal. The strategy called for special action to create an inclusive tariff system that covers all costs beyond day-to-

Table 3. Household waste infrastructure in Ukraine

\begin{tabular}{|l|c|c|c|c|c|c|c|c|}
\hline \multicolumn{1}{|c|}{ Indicator } & \multicolumn{9}{c|}{ Year } \\
\cline { 2 - 9 } & 2013 & 2014 & 2015 & 2016 & 2017 & 2018 & 2019 & 2020 \\
\hline Number of landfills, thousand & 6,7 & 6 & 6 & 6 & 5,5 & 6 & 6 & 6 \\
Landfills area, thousand hectares & 10 & 9 & 9 & 9 & 8,5 & 9 & 9 & 9 \\
Number of waste sorting lines, units & 21 & 21 & 20 & 22 & 25 & 26 & 34 & 34 \\
Number of waste mass-burn facilities, units & 1 & 1 & 1 & 1 & 1 & 1 & 1 & 1 \\
Number of waste incineration units & 3 & 3 & 3 & 3 & 3 & 3 & 3 & 3 \\
\hline
\end{tabular}

Compiled according to [State of circulation] ${ }^{2}$

\footnotetext{
${ }^{2}$ URL: https://www.minregion.gov.ua/napryamki-diyalnosti/zhkh/terretory/
} 
day operations such as aftercare for 35 years, introducing new principles such as "polluter pays" and "extended producer responsibility", improving monitoring and control mechanisms, approving new laws related to the quality of alternative fuels produced from waste and stimulating recycling by all means, including the setup of SRM collection points. All these actions are supposed help to reach a recycling rate of $23 \%$ by 2023 and increasing the separate collection to $23 \%$. The document also set out a plan to replace $20 \%$ of the raw material with secondary alternatives, set up 5,000 separate collection points, and 250 e-waste collection and preparation to reuse points, which should lead to reuse $10 \%$ of e-waste by 2030 . The ultimate goal of the strategy is to increase the amount of waste sent for recycling up to $50 \%$ by building 500 recycling plants and another 500 composting facilities. As a result, the strategy aims to recycle $65 \%$ of all waste and $70 \%$ of the municipal waste by 2030 . The national waste management strategy in Ukraine until 2030 meets the requirements of the EU framework directives in terms of the waste management hierarchy and forms the key benchmarks for a gradual transition to a circular economy. To implement this strategy, a coordination council (the council) was formed as a temporary adviser to the Cabinet of Ministers. The council must ensure the consolidation of the efforts of the local executive authorities in the formation and implementation of state policy in WM.

Normative acts, regulating WM cycle and economic mechanisms of in Ukraine.

The following main normative acts belong to this category:

1. State waste classifier DK 005-96. This waste classification system was approved and put into effect by the State Committee of Ukraine for Standardization, Metrology and Certification in February 1996. Since then, the system has been revised twice in 2000 and 2008. The classifier - in its current form - lags behind the adopted strategy, in particular, the definition of waste neither covers SRM, nor re-use or preparation for re-use. The classifier does not consider the separate collection and recycling of waste.

2. Resolutions of the Cabinet of Ministers No. 1070 "Rules for the provision of services for the handling of household waste" dated December 10, 2008, and No. 1173 "Rules for holding a tender for the provision of services for the removal of household waste" dated November 16, 2011, with amendments and additions. These regulations define the processes and the organization of the household waste management. In accordance with these resolutions, the local government can choose the service provider only on tendering basis in the way prescribed by the law.

3. Resolution No. 1010 "Procedure for the formation of household WM tariffs". This decree was approved by the Cabinet of Ministers in July 2006 and finalized in October 2020. The resolution clearly defined the pricing algorithm of the WM services. According to this resolution, these tariffs consist of the sum of the tariffs for collection, transportation, storage, sorting, processing, recycling, and neutralization. The scope of services in the new edition was expanded to include sorting but excluded tariffs for services related to the separate waste collection. The rates in this resolution was linked to the annual service plan. It established the right to change tariffs depending on the changes in the costs of services. The decree did not include the tariff for waste disposal and the costs associated with the closure of landfills and their remediation. According to the Ministry of Development of Communities and Territories, 424 landfills required remediation and 1542 needed to be audited for re-certification confirmation in 2020 . Such a number of landfills that do not comply with environmental standards require additional sources of funding to bring them in line with the EU Directive on the landfill of waste.

The results of the practical implementation of the tariff formation methodology in Ukraine are presented in tab. 4, where it can be found that the average household waste treatment tariff in 2013-2020 increased more than 3 times, and the waste disposal tariff increased by 3.5 times. The disposal tariff share increased from $29 \%$ in 2013 to $32 \%$ of the total WM tariff in 2020 [17].

Household WM tariffs are set by local municipalities in accordance with the Resolution of the Cabinet of Ministers of Ukraine dated March 27, 2019, No. 318 "Amendments to the Resolutions of the Cabinet of Ministers of Ukraine" according to which, service tariffs are formed on the basis of economically justified planned costs and projected profits. Until 2019, net profit limit was set at $12 \%$, maximum $15 \%$ for budgetary institutions and $50 \%$ for other customers. Resolution No. 318 established the right to change tariffs based on the change of the cost of services. The annual growth of tariffs is influenced by the national policy of annual 
growth of the minimum wage, fuel and lubricants, and spare parts prices.

Results. Analysis of the existing WM legal framework, in the EU/Germany and Ukraine revealed different government approaches to solving the problems caused by the increase of waste general and disposal. The EU legislations cover all WM hierarchy while Ukrainian legislations are generalized and fragmented. The deep dive into the environmental and financial results of the WM legislative framework implementation in Ukraine made it possible to draw a generalizing conclusion about the insignificant changes in the trends in waste generation and processing that lag far behind the trends in the EU. These results are provided below:

1. Prevention and minimization. Household and similar waste generated in Ukraine decreased from
355 million tons in 2014 to 295 million tons in 2017, the trend reversed direction in 2018 and this figure reached 441 million tons in 2019. The production of household and similar waste per capita has shown a continuous growth in the period from 2014 to 2019 from 250 to $260.8 \mathrm{~kg}$ per capita [18].

2. Waste recycling. Official statistics show a negligible amount of recycled waste in Ukraine. The figure is within the limits of the statistical error [19].

3. Green energy production. According to official statistics, the share of household and similar waste sent for incineration to produce electricity in Ukraine ranged from $1.7 \%$ to $2.2 \%$ of all waste generated in the period from 2014 to 2018 [19].

The study showed that the current legislation in Ukraine doesn't align with the WM cycle approved in the strategy. A good example of this is the old

Table 4. Distribution of the WM legislative

initiative between central and local authorities

\begin{tabular}{|c|c|c|}
\hline Phase & Center & Local authorities \\
\hline Generation & $\begin{array}{l}\text { Producer responsibility } \\
\text { Disposal fees } \\
\text { Waste prevention } \\
\text { Waste Trader status } \\
\text { Waste Broker status } \\
\text { Source segregation } \\
\text { End of waste } \\
\text { By-product regulation }\end{array}$ & $\begin{array}{l}\text { Waste bin types and distribution } \\
\text { Minimum infrastructure design requirements } \\
\text { Waste disposal agreements } \\
\text { Penalties for non-compliance } \\
\text { Service providers qualifications criteria }\end{array}$ \\
\hline Transportation & $\begin{array}{l}\text { Licensing } \\
\text { Tracking } \\
\text { Non-mixing } \\
\text { Recording and reporting }\end{array}$ & $\begin{array}{l}\text { Minimum technical requirements } \\
\text { Minimum logistics requirements } \\
\text { Waste collection fees } \\
\text { Drop off centers regulations }\end{array}$ \\
\hline $\begin{array}{l}\text { Recovery } \\
\& \text { recycling }\end{array}$ & $\begin{array}{l}\text { Restriction on secondary raw material disposal } \\
\text { Reuse and recycling of SRM } \\
\text { Bio-waste regulation }\end{array}$ & $\begin{array}{l}\text { Investment stimulation regulations } \\
\text { Recycling promotion and awareness }\end{array}$ \\
\hline Energy recovery & $\begin{array}{l}\text { Minimum waste calorific value allowed for disposal } \\
\text { Emissions limits regulations } \\
\text { Green energy tariffs }\end{array}$ & Investment stimulation regulations \\
\hline $\begin{array}{l}\text { Monitoring } \\
\text { and control }\end{array}$ & $\begin{array}{l}\text { Landfill classification system } \\
\text { Landfill design requirements } \\
\text { Allowed material to be landfilled } \\
\text { Landfill operator responsibilities, landfill lifecycle } \\
\text { management } \\
\text { Establishing waste management indicators } \\
\text { Establishing reporting content and frequency }\end{array}$ & $\begin{array}{l}\text { Designers/operators qualifications criteria } \\
\text { Minimum disposal fees }\end{array}$ \\
\hline
\end{tabular}


waste classification system, which jeopardizes the principle of separate collection adopted in new decrees. In EU regulations, indicators, measurement method and reporting mechanisms with visualization tools are clear, comprehensive, and easily accessible, the best proof of this is the official website of the EU statistics "Eurostat". In Ukraine, the reporting mechanism falls short to deliver clarity on the fulfillment of the plans. The official information provided by the State Statistics Committee (Ukrstat) still lacks data on recyclable waste, produced SRM, recycling data, and still uses an invalid classification, for example, "solid household and similar waste". Statistics of the Ministry of Development of Communities and Territories (annual reports "State of the household waste management in Ukraine") provides incomplete picture on the household waste processing as well.

Conclusions. The information and data presented in this study led to specific recommendations on the improvement of WM legal system in Ukraine considering time and budget constraints, these recommendations can be summarized as follows:

1. Centralized legislation. Obviously, more centralized regulative system has proven to be highly effective and helped the EU/Germany in achieving such impressive results. Centralized rules create consistent practices and facilitate monitoring and control. The proposed legislation distribution for Ukraine is provided in Table 4.

2. Promptness. As Ukraine approaches the deadlines, it becomes more critical to cut all bureaucratic habits and move with much higher speed to issue the required regulations and start their implementation. The attempts to regulate such a matter like the responsibility for packaging waste recycling in Ukraine shows how disappointing the drafting and approval processes are. The initiation of this law started in 2009 by the adoption of the draft Law of Ukraine "On Packaging and Packaging Waste", in 2013 by the draft Law "On Restricting the Production, Use, Import and Distribution of plastic bags in Ukraine" and in 2014 by the draft Law "On packaging and packaging waste". In 2020, the draft Law of Ukraine "On packaging and packaging waste" was posted for public discussion on the official website of the Ministry of Community and Territorial Development. The Law "On Restriction of Circulation of Plastic Bags on the Territory of Ukraine" was approved 1 of June 2021. The Law prohibited the distribution in retail, catering and service facilities ultra-thin plastic bags, thin plastic bags, and oxo-decomposable plastic bags. Delaying the approval of the law to regulate such issue like plastic packaging for 12 years is not acceptable, this pace has to change.

3. Measurability. A key success factors for any WM system is the quality of the feedback provided by data management. To achieve the desired level of awareness, it is recommended to refine the data collection and reporting system to make all relevant data available on UkrStat portal (Table 5).

4. Peeling away method. The waste classification method in Ukraine is outdated. Proper waste classification should help to create a clear road map for waste treatment and facilitate the creation of an effective action plan to minimize waste. The success of the EU/Germany in this area makes it undeniable that reuse, recovery, and recycling prior to disposal is the only viable strategy for Ukraine. Legislatures will need to approve relevant laws and regulations in this regard. These laws should aim to

\section{Table 5. Essential WM data}

to be made available on the public portal

\begin{tabular}{|c|c|}
\hline Phase & Data required \\
\hline Generation & $\begin{array}{l}\text { Total waste generated } \\
\text { Waste generation per capita } \\
\text { Total packaging waste generated } \\
\text { Total packaging waste generation per } \\
\text { capita } \\
\text { Total waste metal generated } \\
\text { Total waste metal generated per capita } \\
\text { Total biowaste generated } \\
\text { Total biowaste generation per capita }\end{array}$ \\
\hline & $\begin{array}{l}\text { Total quantity of secondary raw } \\
\text { material exported }\end{array}$ \\
\hline $\begin{array}{l}\text { Recovery } \\
\& \text { recycling }\end{array}$ & $\begin{array}{l}\text { Total secondary raw material recovered/ } \\
\text { recycled } \\
\text { Total packaging waste recovered/recycled } \\
\text { Total waste metals recovered/recycled } \\
\text { Total biowaste recovered/recycled } \\
\text { Number or recovery/recycling facilities }\end{array}$ \\
\hline $\begin{array}{l}\text { Energy } \\
\text { recovery }\end{array}$ & $\begin{array}{l}\text { Number of energy recovery facilities } \\
\text { Emissions control data per facility } \\
\text { Quantity of waste received } \\
\text { Amount of ash produced } \\
\text { Amount of energy recovered } \\
\text { Number and types of engineered } \\
\text { landfills } \\
\text { Quantity of waste disposed }\end{array}$ \\
\hline
\end{tabular}


- Extended producers, responbility

- End of waste criterria

- Banning organic waste landfilling

- The use of sustainable raw marerial

- Promoting the use of organic fertilizers

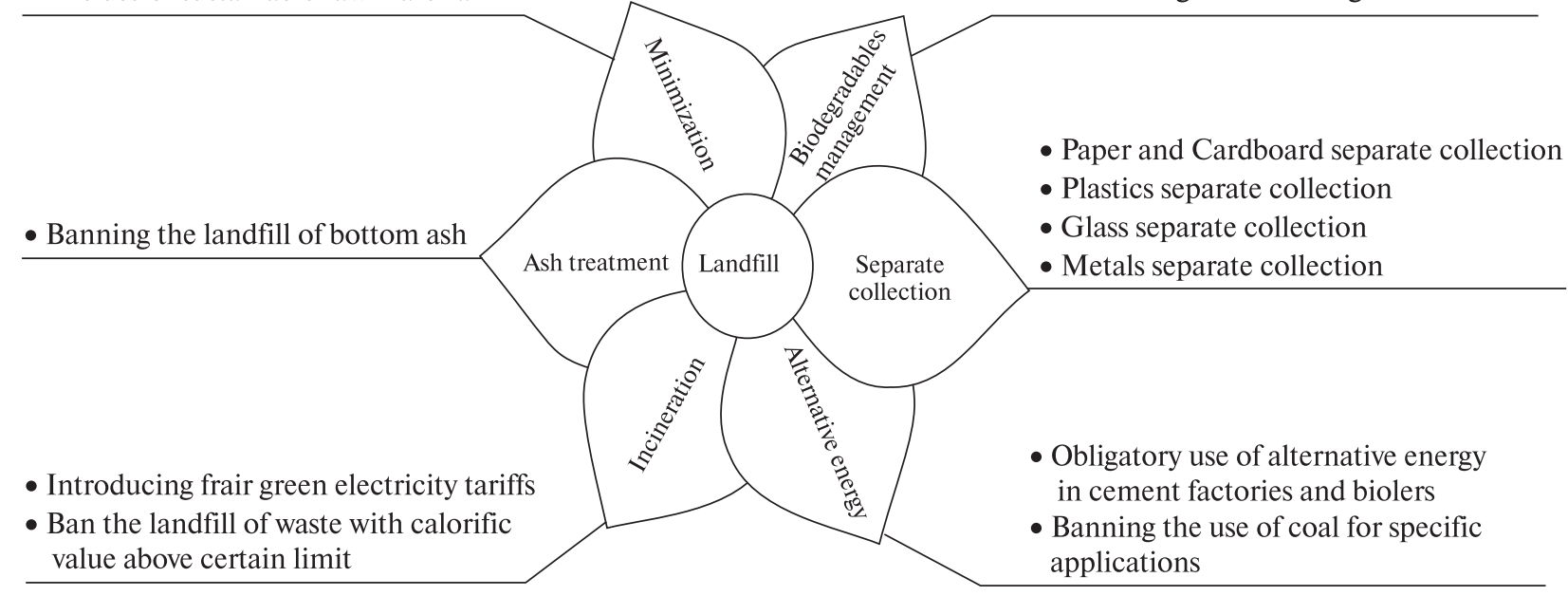

Fig. 2. Peeling away WM method

apply the practice of peeling layers of potential SRM and resources from the waste stream by enforcing certain regulations as shown in Fig. 2.

5. Comprehensiveness and cohesiveness. The WM laws in Germany cover the entire hierarchy and create an integrated system that governs the entire cycle. The legislative system smoothly flows and makes full logic with no ambiguities and contradictions. In Ukraine, centralized laws establish only general rules. Legislative regulation related to critical WM stages (collection, recovery, recycling, disposal) in Ukraine either doesn't exist, or outdated. Critical environmental and operating parameters for such critical processes like waste landfilling and incineration is most critical to be drafted and approved with no abandon to the ones regulating separate collection, reuse and recycling, and alternative fuel.

\section{REFERENCES / СПИСОК ЛІТЕРАТУРИ}

1. Faris. N, Lieberz. S. Changes to Germany's Packaging Laws - An Exporter's Guide. USDA Foreign Agricultural Service, GAIN Report (Germany), 2019. 7 p. URL: https://apps.fas.usda.gov/newgainapi/api/Report/DownloadR eportByFileName?fileName $=$ Changes $\% 20$ to\%20Germany's\%20Packaging\%20Laws\%20-\%20An\%20Exporter's\%20Guide_Berlin_Germany_8-2-2019 (дата звернення: 10.07.2021).

2. Schnurer H. German Waste Legislation and Sustainable Development. Guest lecture by Dr. Helmut Schnurer. International Institute for Advanced Studies (IIAS) in Kyoto/Japan vom 29.11.-1.12.2002. 28 p. URL: https://www.bmu. de/fileadmin/bmu-import/files/pdfs/allgemein/application/pdf/entwicklung_abfallrecht_uk.pdf (дата звернення: 10.07.2021).

3. Weber K., Quicker P., Hanewinkel J., Flamme S. Status of waste-to-energy in Germany, Part I - Waste treatment facilities. Waste Management \& Research: The Journal for a Sustainable Circular Economy. 2020. № 38 (1). P. 23-26. https://doi.org/10.1177/0734242X19894632

4. Zuiev V.A. Mizhnarodno-pravove rehuliuvannia povodzhennia z vidkhodamy: istoriia, suchasnist, perspektyvy. Naukovyi visnyk Dnipropetrovskoho derzhavnoho universytetu vnutrishnikh sprav. 2012. №. 3. Р. 161-168 [Зуєв В.А. Міжнародно-правове регулювання поводження з відходами: історія, сучасність, перспективи. Науковий вісник Дніпропетровського державного університету внутрішніх справ. 2012. № 3. С. 161-168].

5. Zhuk H.V., Nikitin Ye.Ie., Smikhula A.V., Dutka O.V., Ivaniv O.S. Vyznachennia optymalnykh skhem povodzhennia z tverdymy pobutovymy vidkhodamy mist Ukrainy. Jenergotehnologii i resursosberezhenie. 2018. №. 1. P. 48-59. https://doi.org/10.33070/etars.1.2018.07 [Жук Г.В., Нікітін Є.Є., Сміхула А.В., Дутка О.В., Іванів О.С. Визначення оптимальних схем поводження з твердими побутовими відходами міст України. Энерготехнологии и ресурсосбережение. 2018. № 1. С. 48-59. https://doi.org/10.33070/etars.1.2018.07].

6. Popovych N., Malovanyy M., Telak O., Voloshchyshyn A., Popovych V. Environmental Hazard of uncontrolled accumulation of industrial and municipal solid waste of different origin in Ukraine. Environmental Problems. 2018. 
№ 3 (1). P. 53-58. URL: http://science.lpnu.ua/ep/all-volumes-and-issues/volume-3-number-1-2018/environmental-hazard-uncontrolled-accumulation (дата звернення: 10.07.2021).

7. Kryvenko S.V. Vplyv yakosti derzhavnoho rehuliuvannia sfery upravlinnia vidkhodamy na pokaznyky sotsio-ekoloho-ekonomichnoho rozvytku Ukrainy. Visnyk Pryazovskoho derzhavnoho tekhnichnoho universytetu. Seriia: Ekonomichni nauky. 2015. Iss. 29. Р. 181-188 [Кривенко С.В. Вплив якості державного регулювання сфери управління відходами на показники соціо-еколого-економічного розвитку України. Вісник Приазовського державного технічного університету. Серія: Економічні науки. 2015. Вип. 29. С. 181-188].

8. Omelianenko T.L. Reformuvannia orhanizatsiino-ekonomichnoho mekhanizmu povodzhennia z vidkhodamy v Ukraini v konteksti yevrointehratsiinykh protsesiv. Naukovyi visnyk Uzhhorodskoho natsionalnoho universytetu. Seriia: Mizhnarodni ekonomichni vidnosyny ta svitove hospodarstvo. 2015. Iss. 4. Р. 86-92 [Омельяненко Т.Л. Реформування організаційно-економічного механізму поводження з відходами в Україні в контексті євроінтеграційних процесів. Науковий вісник Уэгородського національного університету. Серія: Міжнародні економічні відносини та світове господарство. 2015. Вип. 4. С. 86-92].

9. Makarenko N., Budak O. Waste management in Ukraine: Municipal solid waste landfills and their impact on rural areas. Annals of Agrarian Science. 2017. № 15 (1). P. 80-87. https://doi.org/10.1016/j.aasci.2017.02.009

10. Brauweiler H.-C., Shkola V., Markova O. Economic and legal mechanisms of waste management in Ukraine. Marketing and management innovation. 2017. № 2. P. 359-368. http://doi.org/10.21272/mmi.2017.2-33

11. Kidalov S., Vitiv V., Golovko L., Ladychenko V. Legal Regulation of Waste Management in Ukraine on the Way to European Integration. European Journal of Sustainable Development. 2020. Vol. 9. № 2. P. 422-430. https://doi. org/10.14207/ejsd.2020.v9n2p422

12. Dril N., Galkin A., Bibik N. Applying City Marketing as a Tool to Support Sustainable Development in Small Cities: Case Study in Ukraine. Transportation Research Procedia. 2016. № 16. P. 46-53. https://doi.org/10.1016/j.trpro. 2016.11.006

13. Summary of the current EU waste legislation. Municipal Waste Europe. November 2020. URL: https://www.municipalwasteeurope.eu/summary-current-eu-waste-legislation (дата звернення: 07.06.2021).

14. Tasks and structure. Federal Ministry for the Environment, Nature Conservation and Nuclear Safety. 25.03.2019. URL: https://www.bmu.de/en/ministry/tasks-and-structure (дата звернення: 07.06.2021).

15. Act Reorganising the Law on Closed Cycle Management and Waste of 24 February 2012. Federal Ministry for the Environment, Nature Conservation and Nuclear Safety. URL: https://www.bmu.de/fileadmin/Daten_BMU/ Download_PDF/Abfallwirtschaft/kreislaufwirtschaftsgesetz_en_bf.pdf (дата звернення: 07.06.2021).

16. Translate Municipal waste statistics. Eurostat. URL: https://ec.europa.eu/eurostat/statisticsexplained/index. php?title=Municipal_waste_statistics\#Municipal_waste_generation (дата звернення: 05.07.2021).

17. Stan sfery povodzhennia z pobutovymy vidkhodamy v Ukraini za 2013-2020 rik. Ministerstvo rozvytku hromad ta terytorii Ukrainy. Ofitsiinyi veb-sait. URL: https://www.minregion.gov.ua/napryamki-diyalnosti/zhkh/terretory/ [Стан сфери поводження з побутовими відходами в Україні за 2013-2020 рік. Міністерство розвитку громад та територій України. Офіційний веб-сайт. URL: https://www.minregion.gov.ua/napryamki-diyalnosti/zhkh/ terretory/].

18. UKRSTAT. Economic statistics. Environment. 2020. Waste generation and management. URL: http://www.ukrstat. gov.ua/ (дата звернення: 20.06.2021).

19. UKRSTAT. Economic statistics. Environment. 2020. Household and similar wastes management. URL: http://www. ukrstat.gov.ua/ (дата звернення: 15.06.2021).

Received / Надійшла 08.08.2021

\section{Д.Т.Д. Ель-Рабай'а}

Національний технічний університет України

«Київський політехнічний інститут імені Ігоря Сікорського», Київ, Україна

orcid.org/0000-0001-8912-4664

В.М. Марченко

Національний технічний університет України

«Київський політехнічний інститут імені Ігоря Сікорського» Київ, Україна

orcid.org/0000-0002-4756-3703

\section{ПРАВОВЕ ЗАБЕЗПЕЧЕННЯ ОРГАНІЗАЦІЙНИХ ТА ЕКОНОМІЧНИХ \\ ПРОЦЕСІВ УПРАВЛІННЯ ТВЕРДИМИ ПОБУТОВИМИ ВІДХОДАМИ В ЄВРОПЕЙСЬКОМУ СОЮЗІ ТА УКРАЇНІ}

Розглянуто значні організаційні та економічні ризики, що чекають Україну на шляху до виконання своїх зобов’язань щодо трансформації системи поводження з відходами, яка буде повністю відповідати тій системі, що впроваджується в Європейському Союзі $(\mathrm{EC})$. Щоби виділити основні відмінності та виявити прогалини в 
питаннях, європейське та українське законодавство аналізуються, класифікуються та порівнюються. Екологічні й економічні результати поводження з відходами в Німеччині та Україні свідчать, що Україна не демонструє задовільних поліпшень упродовж останніх семи років з моменту підписання Угоди про асоціацію 3 ЄС. У статті визначено п'ть ключових рекомендацій, які б дозволили Україні впровадити європейські практики у сфері поводження з комунальними відходами (поводження з побутовими відходами згідно з українською системою класифікації). Ці рекомендації узагальнено таким чином: підхід до законодавства, де всі основні нормативні документи затверджені центральним урядом і єдині для всіх регіонів; оперативність та відповідне ставлення до вжиття всіх необхідних заходів, пов'язаних із поводженням з відходами; гарантування вимірності та контролю за кожним етапом поводження з відходами, що має призвести до створення інформативної цифрової бази даних; упровадження «методу очищення» для забезпечення повторного використання всієї потенційної вторинної сировини та відходів з високою теплотворною здатністю, перетворених на альтернативні енергетичні ресурси; створення всеосяжного та злагодженого законодавчого пакета, який працюватиме як цілісна система. «Метод очищення», описаний у цій статті, також уперше використовується для зрозумілого пояснення європейської стратегії мінімізації кількості відходів, що відправляються на сміттєзвалище.

Ключові слова: поводження з відходами, мінімізація, запобігання, переробка, звалища. 